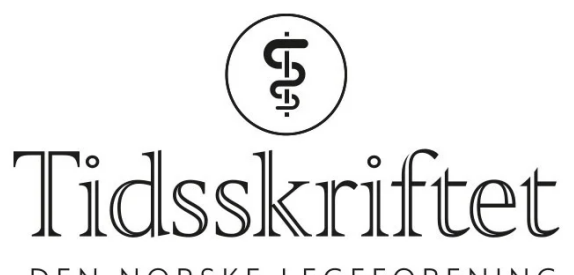

DEN NORSKE LEGEFORENING

\title{
Ginkgo biloba - effekt, bivirkninger og interaksjoner
}

RETTELSE

PÅL-DIDRIK HOFF ROLAND

CECILIE SOGN NERGÅRD

Tidsskr Nor Legeforen 2012; 132: 956-9

I Tidsskriftet nr. 8/2012, side 957, figur 1: Bildet viser ikke Ginkgo biloba, men Adiantum raddianum. Korrekt bilde publiseres her.

I figurteksten skal det stå: Ginkgo biloba.

Vi beklager feilen. Den er rettet i nettutgaven. 


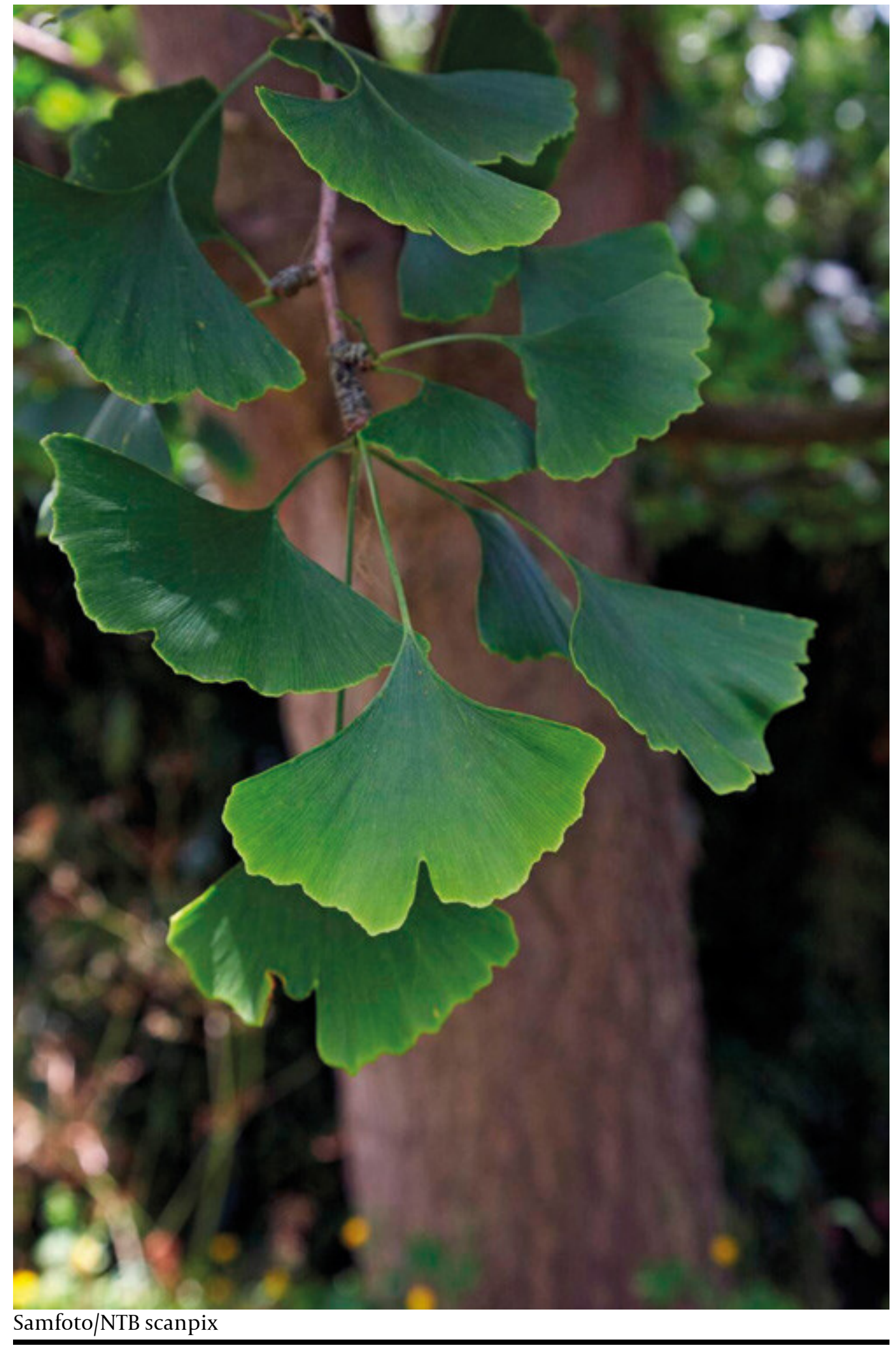

Publisert: 12. juni 2012. Tidsskr Nor Legeforen. DOI: 10.4045/tidsskr.12.0581

(C) Tidsskrift for Den norske legeforening 2023. Lastet ned fra tidsskriftet.no 26. april 2023. 